\title{
THE PROCESS OF OBTAINING QUARTZ SAND SIZE FRACTION $-0.4+0.05$ mm FOR USE IN WATER GLASS PRODUCTION
}

\author{
Slavica R. Mihajlović ${ }^{\prime *}$,Živko T. Sekulićl, Marina S. Blagojev ${ }^{1}$, Miroslav R. Ignjatović \\ ${ }^{1}$ Institute for Technology of Nuclear and Other Mineral Raw Materials, \\ Franchet d'Esperey 86, 11000 Belgrade, Serbia \\ ${ }^{2}$ Chamber of Commerce and Industry of Serbia, 13-15 Resavska Str., \\ Belgrade, Serbia
}

Received 23.01.2019

Accepted 25.03.2019

\begin{abstract}
The paper presents the process of quartz sand processing from the „Bijela Stijena“Skočić deposit in the plant „Kesogradnja d.o.o.“ at Kozluk near Zvornik, Republic of Srpska. Bearing in mind the fact that this quartz sand is used for water glass production in the company „Birač“ - Zvornik or „Alumina“ Zvornik, it was necessary to meet the quality requirements prescribed by that industrial production. Thus, the required size was $-0.4+0.05 \mathrm{~mm}$ and the $\mathrm{Fe}_{2} \mathrm{O}_{3}$ content was maximum of $0.04 \%$. Based on the laboratory tests, a technological scheme for the quartz raw material valorization was conceived in the separation of the company „Kesogradnja d.o.o.“. The obtained results showed that quartz sand for water glass size fraction $-0.4+0.05 \mathrm{~mm}$ could be obtained in the plant. Also, by introducing a magnetic concentration after washing and grading, the $\mathrm{Fe}_{2} \mathrm{O}_{3}$ content was reduced from $0.131 \%$ as it is in the initial sample to $0.038 \%$ which meets the required conditions from the water glass producers.
\end{abstract}

Keywords: quartz sand; separation; magnetic separation; water glass.

\section{Introduction}

The largest producers of quartz sand in the world are the USA, then Germany, Austria, France, Spain, Australia and Great Britain. The predicted growth in demand for quartz sand is $1-3 \%$ per year. The world production of this raw material is about 95 million tons. The practice shows that the highest growth in the use of quartz sand was recorded in the area of flat and particular glass production. The massive quartz sand usage is the industry for water glass production. Withal, what needs to be emphasized is the fact that there are no general quality standards that quartz sand should fulfill to be used in the production of water glass. The quality of quartz sand is determined by its users, that is

* Corresponding author: Slavica Mihajlović, s.mihajlovic@itnms.ac.rs 
water glass producers. In order to achieve the required quality, it is necessary to process quartz sand.

The objectives of quartz sand processing are: achieving the required granulometric composition, increasing the content of $\mathrm{SiO}_{2}$ and reducing the content of the accompanying components that lower its quality. The most frequently used method in the world is the attrition cleaning of quartz sand in combination with gravity and magnetic concentration [1]. In quartz sand or sandstone of any deposit, they are located next to the main component and impurities. In order to eliminate impurities to a greater extent, it is approached to different methods of preparing mineral raw materials [2]. Which procedure will be chosen depends on the content and type of impurities as well as on the way they appear in the quartz raw material. Namely, impurities can be as individual grains, then as surface coatings on quartz grains or as a form of intergrowth with quartz. The grinding processes are used when it comes to sandstone or large-grained sand, whereby the size decreases up to $0.6 \mathrm{~mm}$. Besides the milling (crushing and grinding) processes, washing, attrition scrubbing, grading, gravity concentration, flotation, and magnetic separation are used [3]. Desliming, washing, and grading procedures are used almost always because there is clay present in the quartz raw material as impurities. The scrubbing procedure in attrition machines is used when the quartz surface is kaolinized and limonitised. In this way, the grain is washed and then graded. The flotation concentration procedure in the case of quartz sand is used for assortments in which, besides the quartz, there is mica and feldspar. Then the procedure of the so-called „reverse“ flotation consisting of floating mica and feldspar is applied, and the pure quartz remains in the pulp. Most often, both mica and feldspar are commercial products, which justifies the introduction of this expensive procedure. The flotation concentration is preceded by the washing and grading methods since the clay component must be removed which negatively affects the flotation selectivity of quartz from feldspar and mica [4]. The magnetic separation process is used when, in quartz raw material, besides other impurities, there are also magnetic impurities type $\mathrm{Fe}_{2} \mathrm{O}_{3}$ as carriers of total iron [5-7]. Researchers who are studying the efficacy of the removal of iron as impurities from the quartz raw material by the magnetic concentration method use a mathematical formula that precisely calculates the so-called $\mathrm{Fe}_{2} \mathrm{O}_{3}$ content reduction rate $[8,9]$.

\section{Experimental part}

\section{Deposit data}

The quartz sand deposit "Bijela Stijena"-Skočić belongs to the sediments of the upper Eocene age. It was formed by rinsing sandstone with acidic waters. Sand alluvium has a form of the elongated lens of an irregular shape. They lie over a series of red clay and fine-grained mica sands and a series of brown-red sands, conglomerates, and claystone. The longer axis of the deposit is approximately $420 \mathrm{~m}$, and the shorter $180 \mathrm{~m}$. The thickness of the ore body is $1-33 \mathrm{~m}$, and of the humus-clay cover is $0-2.7 \mathrm{~m}$. About 7.5 ha from the total surface of this deposit have been explored. The deposit is $5 \mathrm{~km}$ away from the separation plant in Kozluk and Zvornik $14 \mathrm{~km}$ [10-12].

Characterization of raw quartz sand

Bearing in mind that examinations of quartz sand from "Bijela Stijena- Skočić" deposit were carried by the request of the company "Birač"-Zvornik apropos "Alumina" Zvornik, which uses this raw material for the production of water glass, it was necessary 
to meet the requirements regarding the quality prescribed by this company, showed in Table 1.

Table 1. Quality of quartz sand for water glass production „Alumina“ Zvornik.

\begin{tabular}{lll}
\hline & $\mathrm{SiO}_{2}$ & 99 \\
& $\mathrm{Fe}_{2} \mathrm{O}_{3}$ & $\max 0.04$ \\
& $\mathrm{TiO}_{2}$ & $\max 0.10$ \\
& $\mathrm{Cr}_{2} \mathrm{O}_{3}$ & $\max 0.0001$ \\
& $\mathrm{Al}_{2} \mathrm{O}_{3}$ & $\max 0.5$ \\
& $\mathrm{Loss}$ on ignition & 0.25 \\
\hline & $\mathrm{K}_{2} \mathrm{O}$ & $\max 0.3$ \\
& $\mathrm{MgO}$ & $\max 0.02$ \\
& $\mathrm{CaO}$ & $\max 0.2$ \\
& $\mathrm{Na} 2 \mathrm{O}$ & $\max 0.1$ \\
\hline & $>0.40 \mathrm{~mm}$ & 4.0 \\
& $>0.30 \mathrm{~mm}$ & 30.0 \\
& $>0.20 \mathrm{~mm}$ & 40.0 \\
& $>0.10 \mathrm{~mm}$ & 26.0 \\
\hline
\end{tabular}

a) Grain size distribution

Grain size distribution of raw quartz sand "Bijela Stijena"-Skočić is shown in Table 2 and graphically presented on Fig. 1.

Table 2. Grain size distribution of raw quartz sand "Bijela Stijena”-Skočić.

\begin{tabular}{lllc}
\hline Size class, $\mathrm{mm}$ & $\mathrm{M}, \% *$ & $\mathrm{M}, \% \downarrow * *$ & $\mathrm{M}, \% \uparrow * * *$ \\
\hline+15.00 & 7.20 & 7.20 & 100.00 \\
$-15.00+4.00$ & 35.34 & 42.54 & 92.80 \\
$-4.00+2.00$ & 6.62 & 49.16 & 57.46 \\
$-2.00+0.60$ & 12.89 & 62.05 & 50.84 \\
$-0.60+0.30$ & 15.33 & 77.38 & 37.95 \\
$-0.30+0.10$ & 15.74 & 93.12 & 22.62 \\
$-0.10+0.05$ & 1.88 & 95.00 & 6.88 \\
$-0.05+0.00$ & 5.00 & 100.00 & 5.00 \\
$* \mathrm{M}, \%-$ weight percent of size fractions in sample, ${ }^{* *} \mathrm{M}, \% \downarrow$ - cumulative oversize, \\
$* * * \mathrm{M}, \% \uparrow-$ cumulative undersize
\end{tabular}




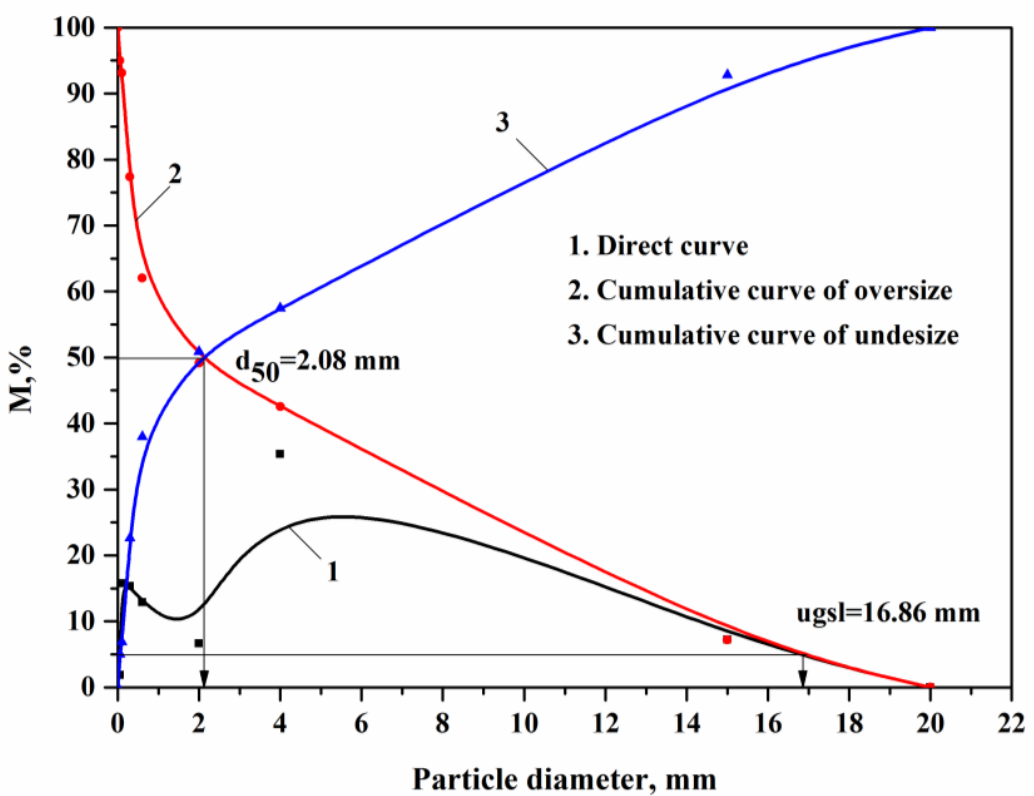

Fig. 1. Curves of the grain size distribution of raw quartz sand "Bijela Stijena"-Skočić.

As to curves of grain size distribution shown on Fig. 1, the determined mean size of the grain is $\mathrm{d}_{50}=2.08 \mathrm{~mm}$ and upper grain limit size class, ugsl $=16.86 \mathrm{~mm}$.

\section{b) Chemical analysis}

Chemical analysis was done on a sample of trench quartz sand, then on the class $0.4+0.05 \mathrm{~mm}$ which represents the required size for use for the production of water glass after washing and after the electromagnet. The obtained results are shown in Table 3 .

Table 3. The chemical composition of trench quartz sand and class $-0.4+0.05 \mathrm{~mm}$ after washing and electromagnet.

\begin{tabular}{llllllllllll}
\hline Sample & \multicolumn{2}{l}{ Content, $\%$} & & & & & & & & \\
& $\mathrm{SiO}_{2}$ & $\mathrm{Al}_{2} \mathrm{O}_{3}$ & $\mathrm{Fe}_{2} \mathrm{O}_{3}$ & $\mathrm{Cr}_{2} \mathrm{O}_{3}$ & $\mathrm{TiO}_{2}$ & $\mathrm{CaO}$ & $\mathrm{MgO}$ & $\mathrm{Na}_{2} \mathrm{O}$ & $\mathrm{K}_{2} \mathrm{O}$ & $\mathrm{LOI}$ \\
\hline Raw quartz sand & 97.82 & 1.24 & 0.131 & 0.0012 & 0.068 & 0.04 & 0.02 & 0.007 & 0.086 & 0.51 \\
\hline $\begin{array}{l}-0.4+0.05 \mathrm{~mm} \text { after } \\
\text { washing }\end{array}$ & 99.15 & 0.29 & 0.075 & 0.0003 & 0.007 & 0.04 & 0.008 & 0.003 & 0.0032 & 0.09 \\
\hline $\begin{array}{l}-0.4+0.05 m m \text { after } \\
\text { electromagnet }\end{array}$ & 99.49 & 0.174 & 0.0301 & 0.0002 & 0.039 & 0.028 & 0.007 & 0.0014 & 0.022 & 0.09 \\
\hline
\end{tabular}

From the shown chemical composition, it can be seen that the trench sample contains $0.131 \% \mathrm{Fe}_{2} \mathrm{O}_{3}$. It can also be seen that the content of $\mathrm{Fe}_{2} \mathrm{O}_{3}$ in the class $-0.4+0.05$ $\mathrm{mm}$ after washing is $0.075 \%$, which is above the prescribed value for use in the production of water glass, that is maximum of $0.04 \%$ (table 1). Consequently, a magnitude concentration on a high-grade magnetic separator in the class $-0.4+0.05 \mathrm{~mm}$ was 
performed in order to remove $\mathrm{Fe}_{2} \mathrm{O}_{3}$. After magnetic separation, the content of $\mathrm{Fe}_{2} \mathrm{O}_{3}$ is reduced to $0.0301 \%$ which meets the required quality prescribed by the user.

On the initial sample, the moisture is $5.0 \%$, while the density is $1.852 \mathrm{t} / \mathrm{m}^{3}$ and the Bond index is $14.0 \mathrm{kWh} / \mathrm{t}$. The density of the class $-0.4+0.05 \mathrm{~mm}$ is also determined, which represents the required size for use in the production of water glass and is 1.42 $\mathrm{t} / \mathrm{m}^{3}$.

c) Determination of the quartz sand granulometric composition that is to be obtained in the separation

Bearing in mind the fact that the required quartz sand size for use in the production of water glass classes is $-0.4+0.05 \mathrm{~mm}$ it was necessary to determine the granulometric composition of the quartz sand which will be obtained in the separation itself. The methods of connecting classes that are going to regrinding in order to obtain the required size are shown in Table 4.

Table 4. Grain size distribution of raw quartz sand that are be obtained by separation.

\begin{tabular}{lllllr}
\hline $\begin{array}{l}\text { Size class, } \\
\mathrm{mm}\end{array}$ & $\mathrm{M}, \%$ & $\mathrm{M}, \% \downarrow$ & $\mathrm{M}, \% \uparrow$ & \multicolumn{2}{l}{ Size class (mm) and content $(\%)$} \\
\hline+15.00 & 7.20 & 7.20 & 100.00 & +15.00 & 7.20 \\
$-15.00+4.00$ & 37.80 & 45.00 & 92.80 & & \\
$-4.00+2.00$ & 4.16 & 49.16 & 55.00 & $-15.00+0.40$ & 63.46 \\
$-2.00+0.60$ & 12.89 & 62.05 & 50.84 & Size class for regrinding & \\
$-0.60+0.40$ & 8.61 & 70.66 & 37.95 & & 24.34 \\
$-0.40+0.05$ & 24.34 & 95.00 & 29.34 & Final product & 5.00 \\
$-0.05+0.00$ & 5.00 & 100.00 & 5.00 & $-0.05+0.00$ & 100.00 \\
\hline
\end{tabular}

Table 4 shows that it is necessary to connect all classes between $-15.00+4.00 \mathrm{~mm}$ and $-0.60+0.40 \mathrm{~mm}$ in the class $-15.00+0.40 \mathrm{~mm}$ which will proceed to regrind. The class $-0.40+0.05 \%$ is the final product with a representation in the total weight of the sample of $24.34 \%$, which can go to direct use.

After the regrinding of large quartz sand classes into the mill with balls, the granulometric composition was determined, and the obtained results are shown in Table 5 and graphically in Fig. 2. 
Table 5. Grain size distribution of quartz sand after grinding of upper size fractions.

\begin{tabular}{llll}
\hline Size class, $\mathrm{mm}$ & $\mathrm{M}, \%$ & $\mathrm{M}, \% \downarrow$ & $\mathrm{M}, \% \uparrow$ \\
\hline+0.60 & 4.35 & 4.35 & 100.00 \\
$-0.60+0.40$ & 7.75 & 12.1 & 95.65 \\
$-0.40+0.05$ & 81.51 & 93.61 & 87.9 \\
$-0.05+0.00$ & 6.39 & 100.00 & 6.39 \\
& 100.00 & - & - \\
\hline
\end{tabular}

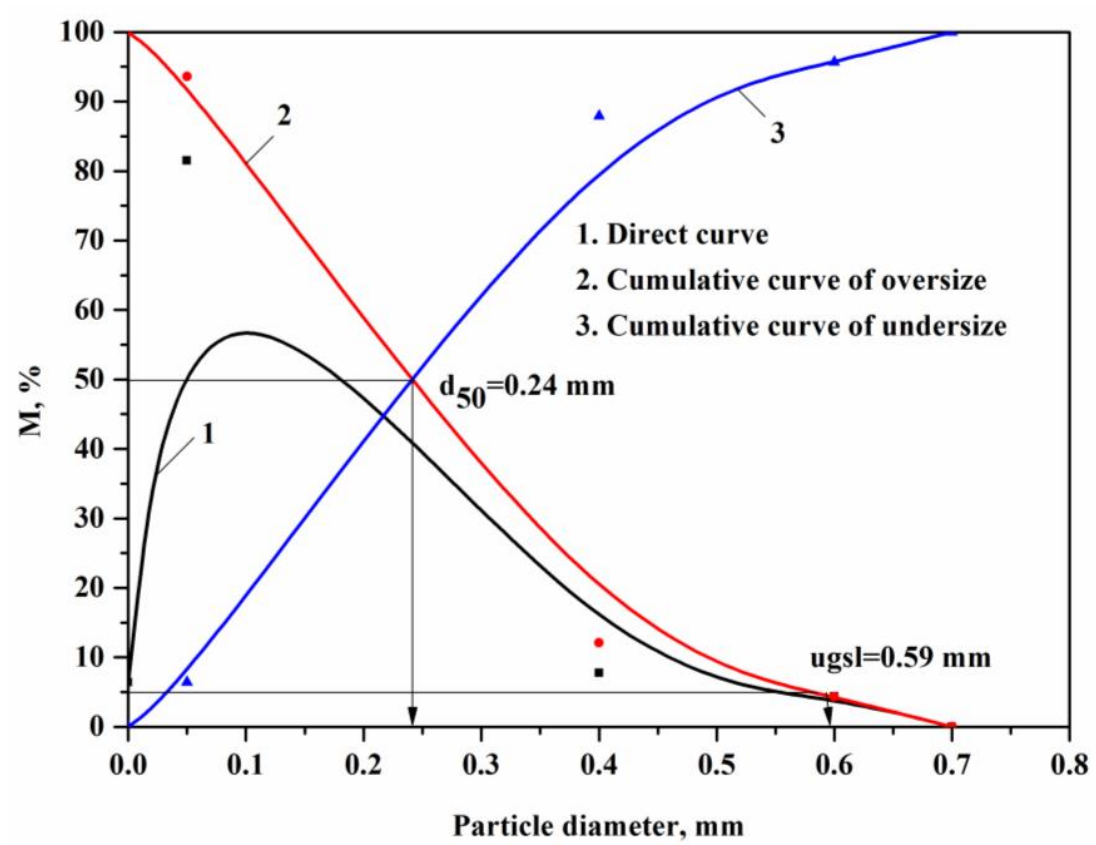

Fig. 2. Curves of the grain size distribution of raw quartz sand after grinding of upper size fractions.

By the results obtained by determining the granulometric composition, it can be seen that by milling the class $-15.00+0.40 \mathrm{~mm}$ a middle diameter was reduced from $2.08 \mathrm{~mm}$, as it was in a trench sample, to $0.24 \mathrm{~mm}$ as it is after its regrinding. Also, the upper grain limit size class $(u g l s)$ was reduced from $16.81 \mathrm{~mm}$ to $0.59 \mathrm{~mm}$.

Description of the technological scheme for obtaining quartz sand and material balance

Based on the tests that were carried out, a technological scheme was developed, after which the valorization of quartz sand "Bijela Stijena"-Skočić in separation Kozluk can be carried out. The technological scheme is given in Fig. 3, and material balance is shown in Table 6. 


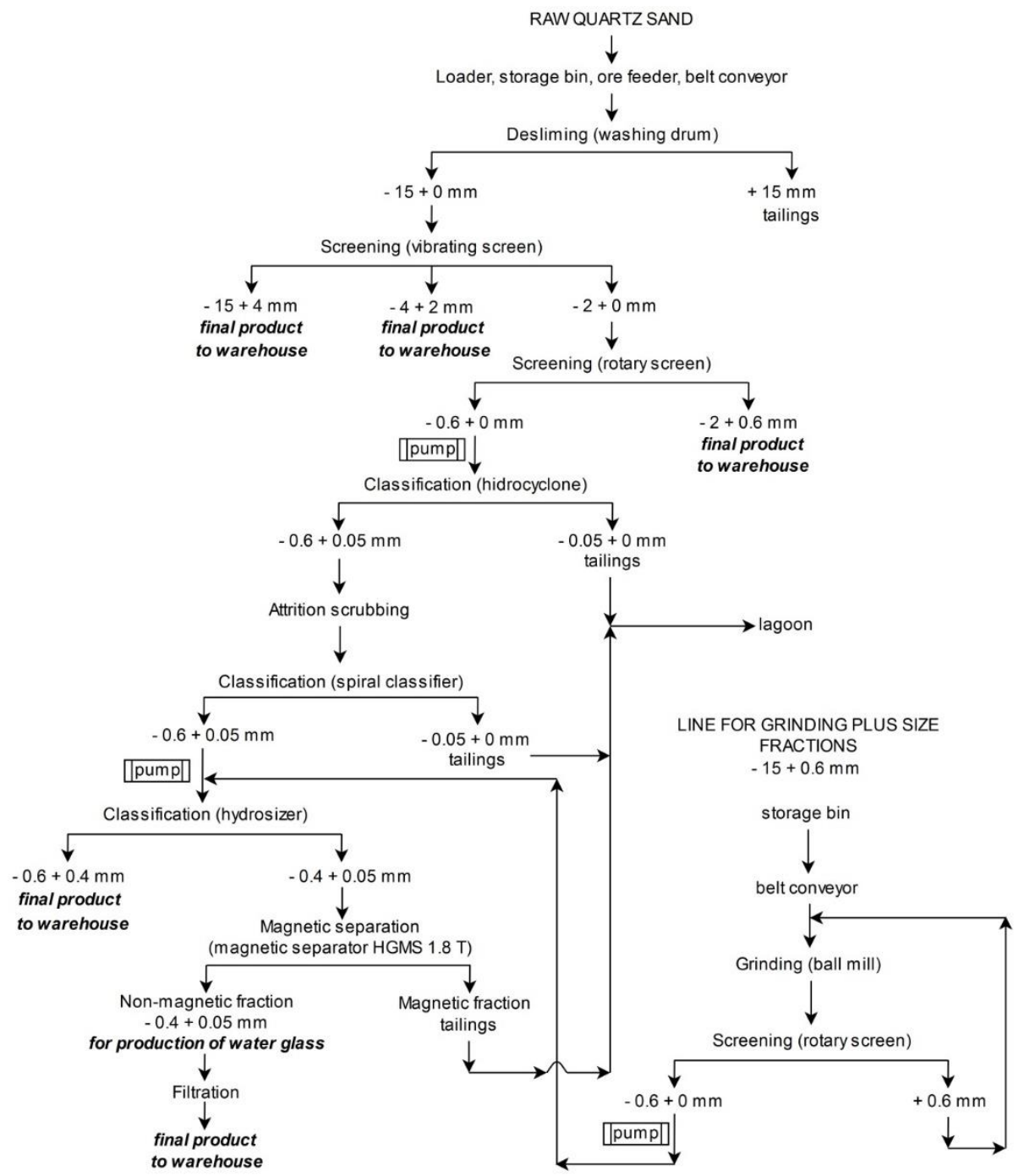

Fig. 3. Scheme of quartz sand valorization "Bijela Stijena” - Skočić in separation Kozluk. 
Table 6. Material balance in the process of separation and milling.

\begin{tabular}{|c|c|c|c|c|c|c|c|c|c|}
\hline \multirow{2}{*}{\multicolumn{3}{|c|}{ Separation }} & \multirow{2}{*}{\multicolumn{2}{|c|}{$\begin{array}{c}\text { Grinding } \\
\text { Feed }\end{array}$}} & \multicolumn{3}{|c|}{ Milling } & \multicolumn{2}{|c|}{$\begin{array}{l}\text { Magnetic } \\
\text { separation }\end{array}$} \\
\hline & & & & & Feed & Productio & & Feed & Outlet \\
\hline Class, mm & & $\%$ & $\mathrm{t} / \mathrm{h}$ & $\mathrm{t} / \mathrm{h}$ & $\mathrm{t} / \mathrm{h}$ & $\%$ & $/ \mathrm{h}$ & $\mathrm{t} / \mathrm{h}$ & $\begin{array}{c}(97 \%), \\
\mathrm{t} / \mathrm{h}\end{array}$ \\
\hline 1 & 2 & 3 & 4 & 5 & 6 & 7 & 8 & 9 & 10 \\
\hline+15.00 & 7.20 & 7.20 & 1.44 & - & - & - & - & - & - \\
\hline$-15.00+4.0$ & 37.80 & 37.80 & 7.56 & 7.56 & - & - & - & - & - \\
\hline$-4.00+2.00$ & 4.16 & & 0.83 & - & Feed in & - & - & - & - \\
\hline$-2.00+0.60$ & 12.89 & 25.66 & 2.58 & - & milling & 4.35 & 0.30 & - & - \\
\hline$-0.60+0.40$ & 8.61 & & 1.72 & - & 7.00 & 7.75 & 0.54 & - & - \\
\hline$-0.40+0.05$ & 24.34 & 24.34 & 4.87 & - & - & 81.51 & 5.71 & 4.87 & 4.72 \\
\hline$-0.05+0.00$ & 5.00 & 5.00 & 1.00 & - & - & 6.39 & 0.45 & - & - \\
\hline Feed & & 100.00 & 20.00 & - & - & 100.00 & 7.00 & - & - \\
\hline $\begin{array}{c}\text { Totals } \\
\text { columns } \\
8+10 \\
\end{array}$ & & & & & $10.43 \mathrm{t} / \mathrm{h}$ & & & & \\
\hline
\end{tabular}

Description of the technological separation process

The quartz sand from the deposit "Bijela Stijena" - Skočić is transported by trucks to the landfill and from there loaded into the receiving bunker, and then dosed with a vibrating feeder to the conveyor belt carrying the raw material into the drum for desliming (the addition of water regulates the density of the pulp). This way formed pulp comes to a $15 \mathrm{~mm}$ open lattice that is located on the exit of the drum.

There is separated the class $+15 \mathrm{~mm}$ that falls on the conveyor belt that goes to the landfill. The class $-15+0 \mathrm{~mm}$ comes in a vibrating sieve. In the sieve, which has two floors, there are assortments $-15+4 \mathrm{~mm}$ and $-4+2 \mathrm{~mm}$, which are transported with conveyor belts to the provided concrete boxes. These assortments are ground in order to obtain the class $-0.4+0.05 \mathrm{~mm}$. The class $-2+0 \mathrm{~mm}$ goes gravitationally, from the vibrating sieve into a rotating sieve where the product $-2+0.6 \mathrm{~mm}$ stands out and falls on the conveyor belt that carries it to the concrete box.

This product can be commercial or ground with other size classes $-15+0.4 \mathrm{~mm}$. The passage of the rotating sieve, $-0.6+0 \mathrm{~mm}$, goes gravitationally into the pump basket and then to the hydrocyclone. The overflow of the hydrocyclone goes gravitationally into a common collector tube that takes it to the lagoon about 150 meters from the plant. The hydrocyclone sand goes to scrubbing in an attrition machine and then gravitationally into a classifier with a spiral in which the required amount of water is added. The overflow of the classifier $-0.05+0 \mathrm{~mm}$ goes gravitationally into the pump basket. The pump transports the overflow to a thickening hydrocyclone. The sand of this cyclone goes into a highgrade magnetic separator, and the overflow in the lagoon together with the hydrocyclone overflow. Classification sand, class $-0.6+0.05 \mathrm{~mm}$, gravitationally goes to the centrifugal 
pump basket. The pump transports the material to a " sitter " that represents the point of connection the materials from the separation and the grinding materials supplied by the pump. From there, the material goes gravitationally into a hydrosizer which has the role is to classify the material on the classes $-0.6 \mathrm{~mm}+0.4 \mathrm{~mm} ;-0.5+0.05 \mathrm{~mm}$ and $-0.05+0$ $\mathrm{mm}$ with the help of water under constant hydrostatic pressure coming from the reservoir for supplying the whole process with water. In the first chamber of the hydrosizers, the class $-0.6+0.4 \mathrm{~mm}$ is separated, and it falls gravitationally onto the conveyor belt and further into the provided concrete box. The class $-0.05+0 \mathrm{~mm}$ from the hydrosizer goes gravitationally into the collector and then into the pump. The class $-0.4+0.05 \mathrm{~mm}$ from the hydrosizer gravitationally comes to the electromagnetic separator. Here a magnetic fraction is obtained, and it gravitationally falls on the conveyor belt that brings out this material to the concrete landfill. The non-magnetic fraction goes to the plan filter where it is thickened so that the product has about $6 \%$ of moisture and then to the warehouse. That is the final product $(-0.4+0.05 \mathrm{~mm})$ which is used for the water glass.

\section{Description of the grinding scheme}

From the separation process, the classes that stand out and go to grinding are $-15+4$ $\mathrm{mm},-4+2 \mathrm{~mm},-2+0.6 \mathrm{~mm}$ and $-0.6+0.4 \mathrm{~mm}$. Also, the oversize $-2+0.6 \mathrm{~mm}$ goes to grinding after control sowing on the rotary sieve. After separation working for a few hours and creating an initial stock of materials that are provided for grinding, the grinding process can begin. These assortments are dosed by the loader to the receiving metal basket located on the grinding line. A feeder is under the basket is that doses this material on a conveyor belt that carries it in a mill with metal balls and rubber coverings. The selection of this mill was carried out to achieve the required quantities of the class $-0.4+0.05 \mathrm{~mm}$, which will then be treated on high-intensity electromagnetic separator by the wet process.

Freshwater from the reservoir is added to the mill in order to achieve a solid-liquid relation: $\mathrm{S}: \mathrm{L}=1: 1$. The ground material comes to the pump basket that sends it to the hydrocyclone. The hydrocyclone sand goes gravitationally to the $0,6 \mathrm{~mm}$ open rotating sieve, and the overflow (water) goes into the pump basket. A control screening is carried out on the rotating sieve in order to obtain the top limit of the final grinding product of $0.6 \mathrm{~mm}$. Therefore, an adequate net is set on the sieve, which enables obtaining the class $-0.6 \mathrm{~mm}$. Freshwater is brought to the rotating sieve from the reservoir. The passage of the sieve goes gravitationally into the pump basket, which transports it to the sitter that is in the separation. It is also the point of joining the materials from grinding and separation.

\section{Conclusion}

Based on technical and technological solutions, the technological scheme of the valorization of quartz raw material from the „Bijela Stijena“-Skočić deposit was conceived in the separation of the company „Kesogradnja d.o.o.“ at Kozluk near Zvornik in the Republic of Srpska. Based on the obtained results it is concluded that the size of the quartz sand for water glass class $-0.4+0.05 \mathrm{~mm}$ can be obtained in the plant. Also, by introducing the magnetic concentration after washing and grading, the $\mathrm{Fe}_{2} \mathrm{O}_{3}$ content was reduced from $0.131 \%$ as it is in the initial sample to $0.038 \%$ which meets the required conditions from the water glass producers. 


\section{Acknowledgments}

This scientific paper resulted from the research funded under the Projects TR 034013 and TR 034006 by the Ministry of Education, Science and Technological Development of the Republic of Serbia from 2011-2019.

\section{References}

[1] D. Vrkljan: Tehnologija nemetalnih mineralnih sirovina, Rudarsko-geološko-naftni fakultet, Zagreb, 2011.

[2] Ž. Sekulić: Kalcijum karbionatne i kvarcne sirovine i njihova primena, Institut za tehnologiju nuklearnih i drugih mineralnih sirovina, Beograd, 2011.

[3] D. Knežević: Priprema mineralnih sirovina, Univerzitet u Beogradu, Rudarskogeološki fakultet, Beograd, 2012.

[4] A.N. Banza, J. Quindt, E. Gock: Int J Miner Process, 79 (2006) 76-82.

[5] R. Ignjatović: Fizičke metode koncentracije mineralnih sirovina, Univerzitet u Beogradu, Tehnički fakultet Bor, 1983.

[6] Z. Sekulic, N. Canic, Z. Bartulovic, S. Mihajlovic, A. Dakovic, In: Proceedings of X Balkan Mineral Processing Congress, Varna, Bulgaria, 2003, p. 627.

[7] Ž. Sekulić, Z. Bartulović, N. Canić, D. Todorović, In: Proceedings of XVIII Mineral Processing Symposium with international, Banja Vrujci, Serbia, 2002, p. 181.

[8] L. Chen, R. Yang, J. Zeng, Y. Shao, Q. Xiao, S. Guo: I J Miner Process, 153 (2016) 66-70.

[9] L.Chen, G. Liao, Z. H. Qian, J. Chen: I J Miner Process, 102-103 (2012) 136-140.

[10] M. Todorović, Geološki elaborat o rudnim rezervama kvarcnog peska ležišta "Bijela Stijena Skočić", 2008.

[11] Glavni rudarski projekat eksploatacije kvarcnog peska ležišta "Bijela Stijena Skočić", Rudarski institut-Prijedor, 2009.

[12] Ž. Sekulić, M. Đokanović, V. Jovanović, B. Ivošević, M. Petrov, A. Daković, In: Proceedings Mining 2010, Tara, Serbia, 2010, p. 34.

\section{(c) (†) Creative Commons License}

This work is licensed under a Creative Commons Attribution 4.0 International License. 